\begin{tabular}{|c|c|c|c|c|c|c|}
\hline \multirow{4}{*}{ Impact Factor: } & ISRA (India) & $=3.117$ & SIS (USA) & $=0.912$ & ICV (Poland) & $=6.630$ \\
\hline & ISI (Dubai, UAE & $=\mathbf{0 . 8 2 9}$ & РИНЦ (Russia & $=0.156$ & PIF (India) & $=1.940$ \\
\hline & GIF (Australia) & $=0.564$ & ESJI (KZ) & $=8.716$ & IBI (India) & $=4.260$ \\
\hline & JIF & $=1.500$ & SJIF (Morocco & $=5.667$ & OAJI (USA) & $=0.350$ \\
\hline
\end{tabular}

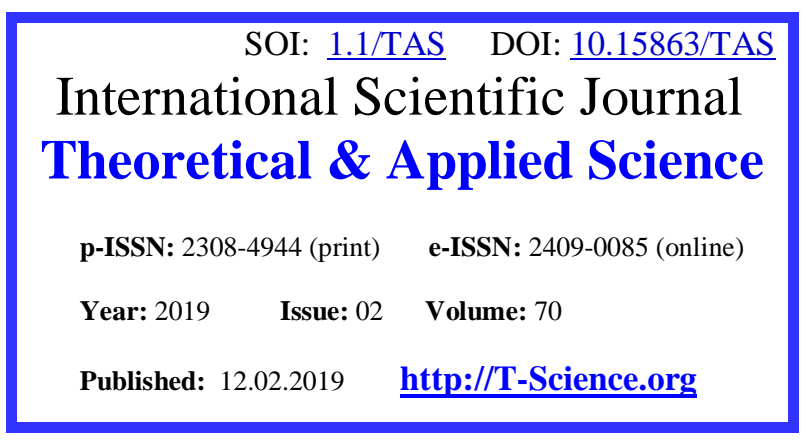

SECTION 29. Literature. Folklore. Translation Studies.

UDC 811.161.1
QR - Issue
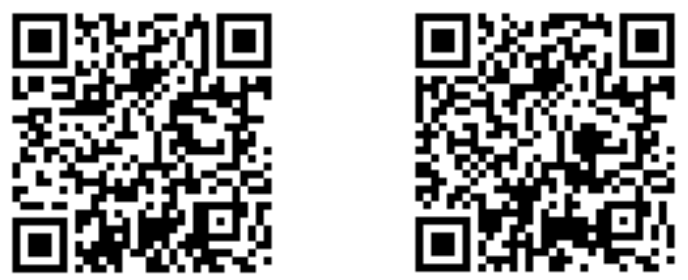

Anna Gennadevna Sheremeteva

Doctor of Philology Sciences, Professor, National University of Uzbekistan, Uzbekistan

Dmitriy Vladimirovich Popov Senior Teacher, Andijan Machine-Building Institute, Uzbekistan

\title{
ON THE LITERARY LANGUAGE OF MOSCOW RUS
}

\begin{abstract}
This article describes the features of the language of the Moscow period, characterized by a bilingual language situation. The function of the literary language was performed by the Slavic and Central Russian language, the language of business writing, influenced both by folk-spoken and Slavic languages. It is a question of the peculiarities of bilingualism, the influence of Hesychasm and the protective attitude to books and language. It is told about changes in the language situation of the middle of the 17th century, about grammatical and genre innovations. The conclusion is drawn that the Slavonic language remained the literary language of Moscow Rus at the end of the 17th century.

Key words: literary language, bilingualism, grammatical features, hesychasm, language tradition, archaization.

Language: English

Citation: Sheremeteva, A. G., \& Popov, D. V. (2019). On the literary language of Moscow Rus. ISJ Theoretical \& Applied Science, 02 (70), 37-40.

Soi: http://s-o-i.org/1.1/TAS-02-70-7 Doi: crossef https://dx.doi.org/10.15863/TAS.2019.02.70.7
\end{abstract}

\section{Introduction}

Thanks to the works of I.I. Sreznevsky [7], A.A. Shakhmatov [11], S.P. Obnorsky [5], V.V. Vinogradov [10], B.A. Larin [2], V.D. Levin [3; 4], B.A. Uspensky [8; 9] and other well-known historians of the Russian literary language, we have such a sum of knowledge and ideas that allows us to reproduce the language picture of Moscow Rus.

The most important feature of the language of the $16^{\text {th }}$ century was that the native speakers of Russian used in their practice the Church Slavonic language along with the Russian. As B.A. Larin states in the $16^{\text {th }}$ century there is a distinct gap between the book-written and spoken language, Church Slavonic texts become incomprehensible even to monks [2, p. 307]. The churchmen who worked on the correction of the liturgical books under the leadership of Maxim the Greek, trying to simplify the language of the old translations, replaced the most common elements of the Old Slavonic language, as they proved incomprehensible even for literate people (for example, $\mathrm{Hbl}-\mathrm{Hac}$, вели -великъ) [2, р. 308].

The following changes in the grammar led to a break between the literary and colloquial language: loss of aorist, imperfect, pluperfect and the formation of one form of past tense on the basis of the form of a perfect without linking; loss of supine; reduction of the finite $-u$ in the suffix of the infinitive; reduction of the endings of verbs in the form of the second person, replacing $\mathrm{CA}$ by $-\mathrm{cb}$ in refuxive verbs; loss of the vocative form; loss of the dual number; loss of declension of short adjectives; replacement of the endings of adjectives with the nominative singular -

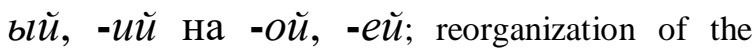
declension system of nouns; alignment of the bases in the back-lingual $\kappa, 2, x$; the use of pronouns меня, тебя, себя instead of lost мене, тебе, себе; the loss of constructions of double accusative and double nominative with replacement for the construction of accusative + instrumental cases; loss of construction dative; archaization of words and replacement with new ones.

\section{Materials and Methods}

In the $16^{\text {th }}$ century. all these signs are no longer neutral, as was the case in the literary language of the 


\begin{tabular}{|c|c|c|c|c|c|c|}
\hline \multirow{4}{*}{ Impact Factor: } & ISRA (India) & $=3.117$ & SIS (USA) & $=0.912$ & ICV (Poland) & $=6.630$ \\
\hline & ISI (Dubai, UAE & $=0.829$ & РИНЦ (Russia) & $=0.156$ & PIF (India) & $=1.940$ \\
\hline & GIF (Australia) & $=0.564$ & ESJI (KZ) & $=\mathbf{5 . 0 1 5}$ & IBI (India) & $=4.260$ \\
\hline & JIF & $=1.500$ & SJIF (Morocco) & $=5.667$ & OAJI (USA) & $=0.350$ \\
\hline
\end{tabular}

$11^{\text {th }}-14^{\text {th }}$ centuries, they become "stylistically marked, being a part of literary language. Genetic Slavisms and archaic Rusisms merged into one category of book elements" [1, p. 103]. The language situation in Moscow Rus of the $15^{\text {th }}$ century is characterized by the opposition of book-written and spoken languages and is a bilingualism. In other words, the literary language and the spoken language no longer fit into one language consciousness and were perceived as different languages. The functions of the literary language were performed by the Slavic and Central Russian languages, the language of business writing, influenced both by folk-spoken and Slavic languages.

It should be noted that the peculiarity of "bilingualism did not consist in the fact that the Slavonic and Russian languages performed different cultural functions and, therefore, supplemented each other, but that they occupied different places in the hierarchical structure of being [1, p. 120]. Slavic scribes sought to protect the language of Scripture from rapprochement with the spoken language, the consequence of which was the archaization and Greekization of Russian graphics and orthography [12]. A significant influence on this was the movement of hesychasm. "Hesychasm has developed and enriched traditional for Orthodoxy symbolic notions about the word, i.e. the idea of an involuntary, unconditional connection between the signifier and the signified" [1, p. 115]. The literary language "cannot and must not adapt to the changeable element of living speech" [1, p. 117]. Thus, the Slavic language was shielded from the penetration of new elements into its system, but at the same time it was closed in itself, which deprived it of further development. The unification of the elements of spoken and book languages in the text "was inadmissible precisely because of considerations of honor and dishonor" [1, p. 120]. Archaization of texts will exhaust itself only by the middle of the $16^{\text {th }}$ century, as L.P. Zhukovskaya, "phenomena in graphics and spelling, which according to tradition are still incorrectly referred to as "the second South Slavic influence", from the middle of the $16^{\text {th }}$ century and in any case, in the second half of this century, they are expelled, and a new orthography begins to take shape" [12, p. 151].

In the Slavonic language, Epiphanius the Wise, the Lives of Sergius of Radonezh and Stefan of Perm were created. The peculiarity of the style of this hagiographer was the "weaving of words": periphrasticity, numerous metaphors and epithets, ranks of synonyms complementing each other, rhetorical questions, an abundance of long words formed from several roots. This way of word formation is alien to the Slavonic language, but it became an indicator of the sublimity of style. Epiphanius the Wise himself composes complex words: доброразумичень, скоровычение, although in the text of the lifestyle himself allows inclusions of Russian words by oversight [2, p. 315]. However, this style of hagiography is "not a rhetorical device as a means of constructing a text, in contrast to South Slavic hagiography, but an effort to express the ideal content in the completeness of enumerations..." [6, p. 6].

In the same Slavonic language works of narrative literature of the $15^{\text {th }}-17^{\text {th }}$ centuries are written: "Zadonshchina", "The Tale of the Princes of Vladimir", "The Tale of the Mamai Battle"; historical and journalistic works: "The grave book royal genealogy", the works of Andrei Kurbsky, Nil Sorsky.

Although linguistic purism did not allow the literary language to draw artistic means from folk speech, there were still authors synthesizing the elements of these languages in their works. A vivid example here will be the messages of Ivan the Terrible and Domostroy.

Thus, the main form of the literary language in Moscow Rus was Slavonic, on which most of the works were created. However, due to the impossibility of penetrating the language of new elements, it was deprived of the prospect of development.

But "right there, close to the protection of the tradition of the "Slavic" language, living with them in the same styles, a living oral speech penetrates deeply into the writing, a struggle is under way for the literary rights of the national language, i.e. written and spoken speech of broad sections of the people" [12, p. 42]. Works created in a language close to the colloquial, Central Russian language, were on the periphery of literature, but their language is characterized by stylistic wealth. A.M. Kamchatnov in his study of the Russian literary language comes to the conclusion that this was the "asymmetry of the language situation in Moscow Rus" [1, p. 140].

An example of the Central Russian language of the $15^{\text {th }}$ century it can be called "The Journey of the Three Seas" by Athanasius Nikitin. In the $16^{\text {th }}-17^{\text {th }}$ centuries. in this close to the spoken language were written "Legend of Magmet-Saltan" by Ivan Peresvetov and "The Tale of the Azov Siege Seat of the Don Cossacks". In these works the book and colloquial elements, the tradition of folklore and ancient Russian literature were synthesized. Here Slavicisms, phonetic and morphological, and elements of colloquial speech (for example, multiple verbs), verbal lexicon and foreign words and concepts are connected.

In the second half of the $16^{\text {th }}$ century the original system of the three styles of the literary language "begins to be formed on the basis of the settlement of the relations between Slavicisms and Russisms" [12, p. 189]. "High style" according to the 


\begin{tabular}{|c|c|c|c|c|c|c|}
\hline \multirow{4}{*}{ Impact Factor: } & ISRA (India) & $=3.117$ & SIS (USA) & $=0.912$ & ICV (Poland) & $=6.630$ \\
\hline & ISI (Dubai, UAE & $=0.829$ & РИНЦ (Russia & $=0.156$ & PIF (India) & $=1.940$ \\
\hline & GIF (Australia) & $=0.564$ & ESJI (KZ) & $=\mathbf{5 . 0 1 5}$ & IBI (India) & $=4.260$ \\
\hline & JIF & $=1.500$ & SJIF (Morocco & $=5.667$ & OAJI (USA) & $=0.350$ \\
\hline
\end{tabular}

classification of M.V. Lomonosov is the immediate heir of the linguistic and stylistic norms worked out in the 16th century [2, p. 311].

In the middle of the $17^{\text {th }}$ century, the language situation changed significantly, and this was due to the political, cultural and religious events that took place, the main of which was the church schism. In the works of the Old Believers you can clearly see how "live folk speech was involved in the semantic atmosphere of the church-written language and, so to speak, "consecrated" to them" [12, p. 44]. Protopope Avvakum creates his messages and Life in a language close to the people's, calling it "vyakanie" (patois). In his texts, Slavs collide with colloqualisms, book concepts are explained by synonyms from the national language adapting to colloquial speech and so everyday comprehension of Slavonic words, phraseological units takes place. Habakkuk for stylistic purposes, for expressing contempt for apostates, in one phrase combines sublime Slavonic vocabulary and colloquial sharp expressions, seeking an acute artistic effect. He widely uses diminutive names in the texts to express a warm relation to the addressee or subjects that evoke good memories. Such a functioning of words with diminutive caressing suffixes for stylistic purposes was especially characteristic, according to observations

by

B.A. Larin, for the language of proverbs of that time [2, p. 333, 334]. Slavic phraseology, through its neighborhood with vernaculars, is deprived of its high-spiritedness. "The same images fluctuate between biblical and everyday conversational speech" [12, p. 47].

The syntax of Avvakum's works is affected by colloquial, simple Russian speech: the alternation of short sentences, rare participial adherences, the absence of a period, the predominance of the copulative conjunction over the subordinate - all this makes the texts of Archpriest Avvakum dynamic, understandable to the simple reader.

The language of Avvakum's works, combining bookish and colloquial, Slavic and Russian, destroyed the bilingualism that prevailed in Moscow Rus, anticipating the fate of the Russian literary language [1, p. 218].

As for the grammar of the language of the $17^{\text {th }}$ century, here the phenomena that will be characteristic of the language of the $18^{\text {th }}-19^{\text {th }}$ centuries are confirmed: the volume of categories of animation and incanimation, the system of pronoun word changes, the system of word changes of compound numbers; development and consolidation of new forms of syntactic communication (with the conjunctions if, because, due to) [12, p. 189].

In the second half of the $17^{\text {th }}$ century. there are parodic satirical works ("Service tavern"), household story. And in them, too, as in the writings of the archpriest Avvakum, "the unification of heterogeneous elements in new stylistic unity" takes place [1, p. 222], although on the periphery of literature.

\section{Conclusion}

The Slavonic language remained the literary language of Moscow Rus at the end of the $17^{\text {th }}$ century, greatly expanding its influence thanks to the baroque culture, giving preference to solemn panegyrics, didactic poetry, school dramas.

\section{References:}

1. Kamchatnov, A. M. (2005). The history of the Russian literary language: 11 - the first half of the 19 century. Moscow: Academy.

2. Larin, B. A. (2005). Lectures on the history of the Russian literary language $(10$ - middle of the 18 centuries.). St. Petersburg: Avalon.

3. Levin, V. D. (1958). Short feature article of the history of the Russian literary language. Moscow: Nauka.

4. Levin, V. D. (1964). Essay on the stylistics of the Russian literary language of the end of the $18^{\text {th }}$ - beginning of the $19^{\text {th }}$ century. Vocabulary. Moscow: Nauka.
5. Obnorsky, S. P. (1946). Essays on the history of the Russian literary language of the older period. Moscow: Academy.

6. Rogozhnikova, T. P. (2003). Hagiography of the "Makaryevsky cycle": Genre and style. St. Petersburg: Publishing House of St. Petersburg University.

7. Sreznevsky, I. I. (2003). Materials for the dictionary of the Old Russian language: In 3 volumes. Moscow: Znak.

8. Uspensky, B. A. (1994). Short feature article of the history of the Russian literary language. Moscow: Gnozis. 


\begin{tabular}{|c|c|c|c|c|c|c|}
\hline \multirow{4}{*}{ Impact Factor: } & ISRA (India) & $=3.117$ & SIS (USA) & $=0.912$ & ICV (Poland) & $=6.630$ \\
\hline & ISI (Dubai, UAE & $=0.829$ & РИНЦ (Russia & $=0.156$ & PIF (India) & $=1.940$ \\
\hline & GIF (Australia) & $=0.564$ & ESJI (KZ) & $=\mathbf{5 . 0 1 5}$ & IBI (India) & $=4.260$ \\
\hline & JIF & $=1.500$ & SJIF (Morocco & $=5.667$ & OAJI (USA) & $=0.350$ \\
\hline
\end{tabular}

9. Uspensky, B. A. (2002). The history of the Russian literary language $\left(11^{\text {th }}-17^{\text {th }}\right.$ centuries). Moscow: Aspekt-Press.

10. Vinogradov, V. V. (1978). The history of the Russian literary language. Selected works. Moscow: Nauka.

11. Shakhmatov, A. A. (1916). Introduction to the course of the history of the Russian language. St. Petersburg.
12. Zhukovskaya, L. P. (1987) Greekization and archaization of the Russian letter of the second half of the $15^{\text {th }}$ - first half of the $16^{\text {th }}$ centuries. (about the fallacy of the concept of "second South Slavic influence") / Old Russian literary language in its relation to the Old Slavonic. (pp.144-176). Moscow: Nauka. 